\title{
PAPERS ON FORMAL LINGUISTICS
}

No. 4 



\title{
The Definite Article in
}

\section{English}

\section{Transformations}

\author{
by \\ BEVERLY LEVIN ROBBINS \\ UNIVERSITY OF PENNSYLVANIA
}

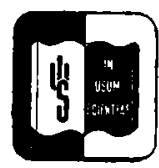

1968

MOUTON \& CO

THE HAGUE - PARIS 
(c) Copyright 1968 in The Netherlands.

Mouton \& Co. N.V., Publishers, The Hague.

No part of this book may be translated or reproduced in any form, by print, photoprint, microfilm, or any other means, without written permission from the publishers.

LIBRARY OF CONGRESS CATALOG CARD NUMBER: 68-17898

Printed in The Netherlands by Mouton \& Co., Printers, The Hague. 